\title{
THE IMPLEMENTATION OF POLICIES FOR ON-TIME PRESENTION IN EFFORTS TO ESTABLISH DISCIPLINE CHARACTER
}

\author{
Susamta'), Fitri Nur Mahmudah ${ }^{2)}$ \\ 1,2 Magister Manajemen Pendidikan, Universitas Ahmad Dahlan, Yogyakarta Indonesia \\ email:ssusamta@gmail.com, fitri.mahmudah@mp.uad.ac.id
}

\begin{abstract}
Discipline is the most important part in the development of the era. This aims to be able to increase teacher self-awareness and critical thinking skills. This study aims to determine the application of teacher discipline. Research setting at SMP Muhammadiyah 9 Yogyakarta. The resource persons in this study were teachers. Data collection techniques using observation and interviews. The research procedure used the Stake model, and data analysis assisted by Atlas.ti version 8 . The results of this study indicate that there are several indicators in implementing timely presence policies for teachers to be able to improve character during covid-19, namely rules, role models of behavior, development., attandance, and impact. The novelty of this study is a different indicator from previous research that can be used as a study material and a basis for teacher behavior to improve performance, work ethic, productivity, and the ability to always apply disciplined time in any activity.
\end{abstract}

Keywords: disciplin, self-awareness, teacher, character enhancement

\section{Abstrak}

Kedisiplinan menjadi bagian terpenting dalam perkembangan era. Hal ini bertujuan untuk mampu meningkatkan kesadaran diri guru dan kemampuan berfikir kritis. Penelitian ini bertujuan untuke mengetahui penerapan kedisiplinan guru. Seting penelitian di SMP Mubammadiyah 9 Yogyakarta. Nara sumber dalam penelitian ini adalah guru. Teknik, pengambilan data dengan menggunakan observasi dan wawancara. Prosedur penelitian menggunakan model Stake, dan analisis data dengan berbantuan Atlas.ti versi 8. Hasil penelitian ini menunjukkan bahwa terdapat beberapa indikator dalam implementasi kebijakan presensi tepat waktu bagi guru untuk dapat meningkatkan karakter selama covid-19 yaitu rule, role model of behavior, development, attandance, dan impact. Novelty dari penelitian ini adalah indikator yang berbeda dari penelitian sebelunya yang dapat digunakan sebagai bahan kajian dan dasar perilaku guru untuk dapat meningkatkan kinerja, etos kerja, produktivitas, dan kemampuan untuk selalu menerapkan waktu disiplin dalam aktivitas apapun.

Kata kunci: kedisiplinan, kesadaran diri, guru, peningkatakan karakter

\section{INTRODUCTION}

Discipline is an attitude of one's obedience in all activities and activities. Discipline is an important thing that needs to be formed by someone in the family, community, and work environment (Habibi \& Supriatno, 2020; Rofiq, 2017). The difference is, in a work environment, discipline has measurements and provisions (Rosyad \& Maarif, 2020). In addition, regulations are also things that must be obeyed. This is as in the Republic of Indonesia Government Regulation no. 53 of 2010 that "the ability to comply with obligations and avoid the prohibitions specified in the statutory regulations and/ or criminal regulations which if not obeyed or violated shall be subject to disciplinary action"(Pemerintah Indonesia, 2010, p. 7). Discipline is an attitude of obedience. The basis of this attitude of obedience is the habit of living and living in regular teaching 
and learning. Therefore discipline is a provision for employees to become an obligation.

One form of teacher discipline is on time attendance. This is evidenced by presence. The tools used are various, using fingerprint, facial presence, and also other tools. The media is used to avoid cheating that occurs. An indicator of the achievement of teacher discipline is when there is an accurate report without being manipulated (Ma`arif, 2018; Nur Hakim \& Rahayu, 2019). One of them is in carrying out their duties, teachers, and employees are required to be able to provide examples of work discipline. Therefore it requires discipline for undisciplined teachers. Discipline is an attempt to instill oneself so that you are able to follow the rules. This is in accordance with what was conveyed by (Mahmudah, 2016, p. 6) that "discipline is a human investment that an educator needs to have so that it creates a sense of responsibility and improves critical thinking skills". The most important part of the process of obeying the rules is self-awareness as evidenced by willingness, ability, and insecurity.

The problem that occurs is the low selfawareness of teachers and employees in being on time. Many factors influence and need to be explored. As in research conducted by (Pramiyati, 2014, p. 52) who said that "the problem of teacher discipline increases with an indicator of a lack of habits and teacher consistency in work". Every regulation and policy established by the government is created to fulfill the realization of a good and quality public service. The use of the fingerprint electronic attendance system in government offices is a regulation that comes from the central government which is then developed for each regional government. The policies set by the government have a goal in each of them. The number of disciplinary cases found in every government agency throughout Indonesia is a problem that requires the best solution in its handling.

Based on the above background, the purpose of writing this article is to determine the timely application of attendance policies in an effort to shape the disciplinary character of educators at SMP Muhammadiyah 9 Yogyakarta.

\section{RESEARCH METHOD}

The method used in this research is qualitative research with a case study approach. The reason for choosing to use the case study model is to reveal facts in the field related to discipline. Participants in this study were teachers who taught at SMP Muhammadiyah 9, Yogyakarta. Data collection techniques using observation and interviews. The research procedure uses the Stake model, 2010. The steps are as follows: 
1) Case selection, by reviewing previous research related to discipline relevant to real conditions at SMP Muhammadiyah 9 Yogyakarta. 2) Furthermore, data collection is carried out by observation and interview methods. Observations are made by observing the real conditions of how teachers and employees perform presence. The researcher observed in the distance until the time of entry. And note the teachers who come to work on time. Interviews were conducted with teachers in schools to reveal facts in the field. 3) Data analysis in this study using the Atlas.ti software version 8. 3) Refinement, carried out to improve and improve the quality of research related to teacher discipline 4) Reports. The final result of this research is a report made in the form of an article and then submitted to a national scientific journal indexed by Sinta

\section{RESULT AND DISCUSSION}

Various technological innovations are increasingly helping to solve problems in teacher discipline. The attendance policy is based on the objective of making it easier to collect data on teachers and employees and to monitor their attendance. Increasing the discipline of teachers and employees is one of the goals of implementing the attendance policy at SMP Muhammadiyah 9. This is due to the many cheatings that are often committed by teachers and employees in manual attendance. In addition to increasing discipline, data from attendance policies are also used as a reference for calculating employee benefits.

In order to discipline teachers and employees, the Principal of SMP Muhammadiyah 9 Yogyakarta, implemented a presence policy. In addition, this policy was implemented to make it easier for the principal to see the level of discipline of each teacher and employee. Because so far in manual attendance (only in the form of an attendance list), the principal, teachers and other employees who see attendance cannot know the level of discipline of teachers and other employees, the problem is manual attendance there is no information when the employee comes and goes home, employees can combine on other days or leave absences to other employees. So that this policy is implemented as a manifestation of improving the use of manual attendance which is considered ineffective and efficient in its application.

The discipline of the teacher before and after the attendance policy is that the teacher in taking attendance becomes more orderly both morning and afternoon even though the teaching hours are still noon, different from before the application of the attendance policy, teachers come to school only when there are teaching hours even though they are signed at attendance still 
made at 07.00 WIB. They have an orderly presence online for fear of being late or going home early. It turns out that they do this so that their additional employee income is not reduced according to the work hour load, because the provision of additional employee income benefits is given based on attendance data from an online fingerprint machine. From the previous description, it was found that the attendance policy aims to discipline teachers and employees, especially in terms of attendance. With the implementation of the new policy on attendance, teachers are required to run the electronic presence and become more orderly and disciplined.
After the data was collected, the analysis was carried out using the Atlas.ti software version 8. Starting from transcribing the data from observations and interviews, then the researchers conducted data reduction by selecting the data used and relevant to the topic of the implementation of teacher and employee discipline implementation studies. This is the main reference to be used as the next stage of analysis, namely the creation of categories and the final result of the study, namely the research concept map. The following are the results of research data analysis.

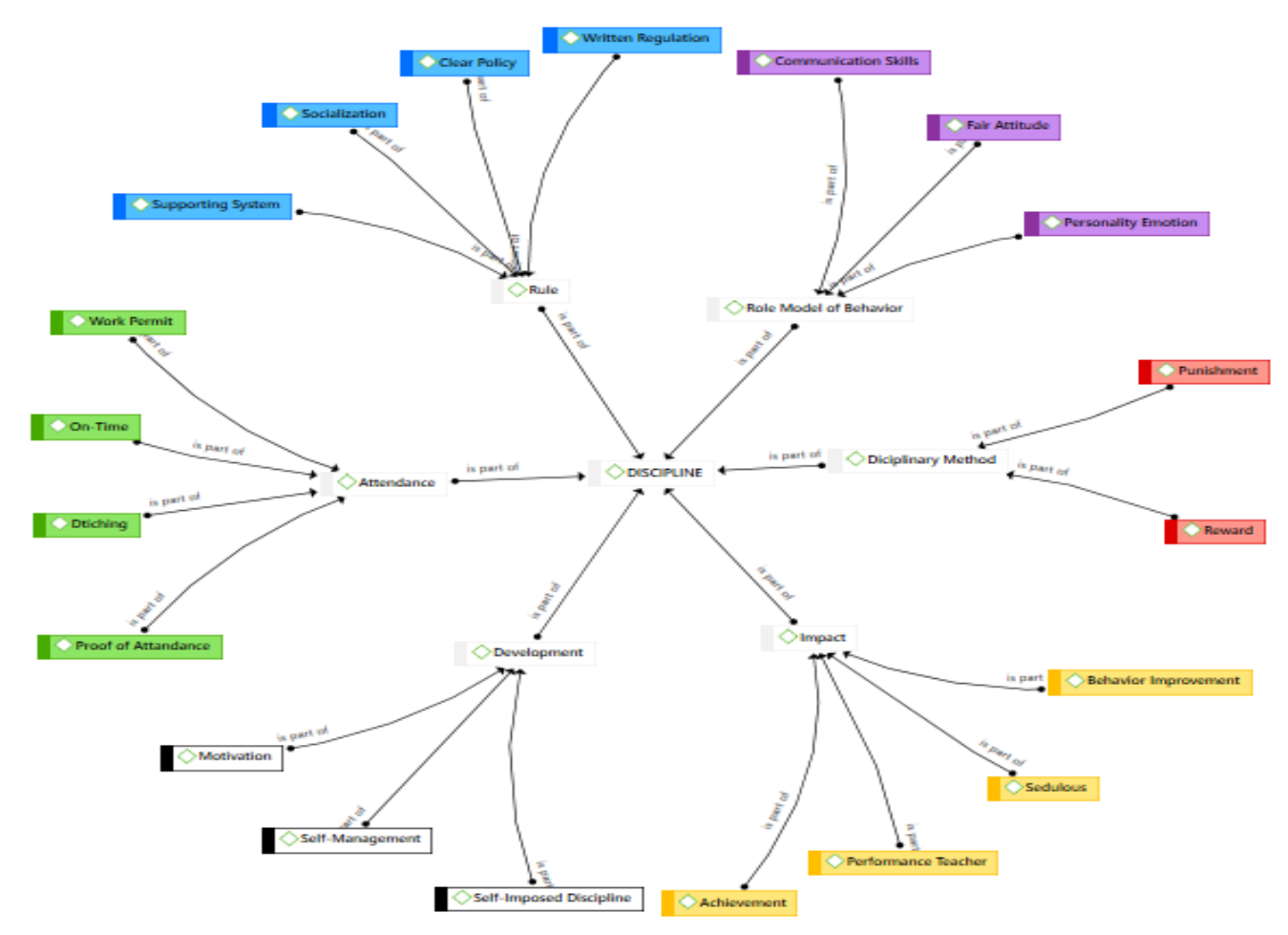

Figure 1.Disciplinary Research Data Analysis Results Assisted by Atlas.ti Software version 8 Source: Output/Result from Qualitative Data Analysis by Atlas.ti Softwere version 8. 
Based on Figure 1 of the research results above, it can be explained that in this study there are several indicators of teacher discipline, namely: rules, role models of behavior, disciplinary methods, development, attendance, and impact. The indicators of the findings of this study still have different components from one another. The findings of this study will be discussed in depth as follows:

\section{Rule}

Rule is a policy that ensures the stability of teachers and employees in schools. This rule has certain indicators in each development. Based on the research results, it was found that the indicators of rules for the implementation of presence policy on time are written regulations, clear policies, socialization, and supporting systems. This indicator is the most important part in implementing the presence policy at SMP Muhammadiyah 9 Yogyakarta. According to (Roos, 2003, p. 34) that "the legal nature of schools, codes of conduct and disciplinary proceedings in schools". The same thing was also conveyed by (Mahmudah \& Cahya, 2020 , p. 12) that "rule is one of the ways to cultivate knowledge, skills, and attitudes of teachers and employees". Therefore, rules are the main and most important part of regulating all implementation, especially those related to the presence of teachers and employees.

\section{Role Model of Behavior}

Role models of behavior are concrete examples developed from everyday attitudes. These examples are the most important part of learning non-manipulated Life Skills. It is seen in reality and can support the culture and school climate from the positive attitude that is carried out. The findings of this study, the role model of behavior has several indicators, namely communication skills, fair attitude, and personality emotion. These three indicators are factors that can make a person have a role model of behavior. In line with the findings and statements, according to (Hurd \& Zimmerman, 2011, p. 3) say that "role model behaviors may be a crucial determinant of youth atti- tudes and behaviors, particularly among early adolescents". The same statement (Morgenroth \& Peters, 2015, p. 1) state "role models are often suggested as a way of motivating individuals to set and achieve ambitious goals, especially for members of stigmatized groups in achievement settings". Also according to (Kedia, Brohmer, Scholten, \& Corcoran, 2019) bahwa "role models arouse could thus help people regain control over their lives".

\section{Diciplinary Method}

Discipline method is one of the things to measure the success of the presence on time. There are two methods found from 
the results of this study, namely punishment and reward. The attendance policy will be more effective if there are provisions that regulate such as punishment and rewards for teachers and employees. According to (Ensom, Rsw, Assembly, Nations, \& States, 2012, p. 1371) that "punishment is associated with a range of mental health problems in teacher and employee, including depression, unhappiness, anxiety, feelings of hopelessness, and general psychological maladjustment". The aim is to provide written advice on what the teacher has violated, namely indiscipline. According to (Ndofirepi, Makaye, \& Ndofirepi, 2012, pp. 82-90) that "the purpose of punishment is to treatment, change, and increasing of the attitude". While the award is part of the support for the discipline of teachers and employees so that they get something to be happy about. According to (Rumokoy, 2019, p. 471) States that "the reward that given by the company and it drive the employee's motivation to work harder and make a better performance". Therefore, the importance of this method is applied in supporting the timely attendance policy for teachers and employees.

\section{Development}

The development of the attitudes of teachers and employees is a step that needs to be done continuously in order to be able to do work in accordance with the established regulations. This selfdevelopment which is found from the results of the analysis of this research includes motivation, self-management, and self-imposed discipline. Developing selfdiscipline aims to turn an activity that is selfish into part of school rules. According to (Gorbunovs, Kapenieks, \& Cakula, 2016, p. 1) state that "a self-discipline in daily routine knowledge acquisition process could be considered as a key parameter to improve learning outcomes". The same statement was also made by (Chairilsyah, 2019, p. 1) state that "discipline needs to start as early as possible starting from within the family, the educational environment, and the community environment". The same thing was also conveyed by (Adlya, Yusuf, \& Effendi, 2020, p. 2) that "discipline is a behavior that reflect obedience, adherence, and orderliness to rules, regulation and valid values in community or society especially in school".

\section{Attendance}

The presence of teachers and employees can be seen from the physical presence in the room. This presence is the main characteristic when schools carry out assessments. Various evidences can be used as material to assess teacher attendance whether it is in accordance with the expected goals or not. The analytical 
findings of this study provide information related to indicators of teacher attendance, namely in the form of on-time, ditching, work-permit, and proof of attendance. According to (Obeng-denteh, 2011, p. 4) state that "it is an expectation that an employee who is hired to perform a job attend work on a regular basis in order that scheduled work assignments can be carried out by the most appropriate staff without disruption to other staff'. Menurut (Jacobson, 2019, p. 8) state that "the first perspective views chronic absenteeism as the ultimate manifestation of deep-seated employee job dissatisfaction". There are factors that cause teachers to be absent.

Based on the discussion above, it can be concluded that the application of electronic presence (fingerprint) shows that the level of teacher discipline is better, teachers feel afraid and embarrassed if they arrive late to school. They still try to arrive earlier than usual to make attendance even though the teaching time is still noon. Teachers become more orderly and disciplined in attending school because they do not want their workload to decrease, if this reduces it will affect the amount of allowances they receive.

\section{CONCLUSION}

Based on the results of the research and discussion above, it can be concluded that the timely attendance policy for teachers and employees is very important to be paid attention to by the principal and by himself. This aims to increase a positive attitude and character related to self-awareness in obeying the rules. This timely presence is a form of teacher discipline which is the basis for self-development. The impact of discipline seen from these findings is to be able to improve teacher performance and achievement. With the implementation of the presence policy at SMP Muhammadiyah 9 Yogyakarta, the discipline of teachers and employees at work provides real information regarding things that must be considered and done. It aims to be able to increase a higher work ethic. This ability needs to be realized by each teacher and employee in order to be able to align personal needs and organizational behavior in achieving common goals.

\section{REFERENCES}

Adlya, S. I., Yusuf, A. M., \& Effendi, Z. M. (2020). The contribution of self control to students, discipline. Journal of Counseling and Educational Technology, 3(1), 1-5.

Chairilsyah, D. (2019). Educating children to be a discipline person. Jurnal PAJAR (Pendidikan Dan Pengajaran), 3(9), 12821288.

Ensom, R., Rsw, M. S. W., Assembly, G., Nations, U., \& States, U. (2012). Physical punishment of children: 
lessons from 20 years of research. CMAJ, 184(12), 1373-1377. https://doi.org/10.1503/cmaj.121070

Gorbunovs, A., Kapenieks, A., \& Cakula, S. (2016). Self-discipline as a Key Indicator to Improve Learning Outcomes in e-learning Self-discipline as a key indicator to improve learning outcomes in e- learning environment. Procedia - Social and Behavioral Sciences, 231(November), 256-262. https://doi.org/10.1016/j.sbspro.2016 .09 .100

Hurd, N. M., \& Zimmerman, M. (2011). Role model behavior and youth violence: a study of positive and negative effects. The Journal of Early Adolescence, $\quad$ 1(4), 323. https://doi.org/10.1177/02724316103 63160

Jacobson, S. L. (2019). Attendance incentives and teacher absenteeism. In Planning and Changing (p. 81).

Kedia, G., Brohmer, H., Scholten, M., \& Corcoran, K. (2019). Improving selfcontrol: the influence of role models on intertemporal choices. Original Research, $\quad 10(8)$, 1-12. https://doi.org/10.3389/fpsyg.2019.01 722

Mahmudah, F. N. (2016). Keefektifan Human Capital Investment Pendidikan Tenaga Kependidikan di Universitas
Negeri Yogyakarta. Jurnal Akuntabilitas Manajemen Pendidikan, 4(1), 77-87. Retrieved from https://doi.org/10.21831/amp.v4i1.82 01

Mahmudah, F. N., \& Cahya, E. (2020). What makes employees productive and have high performance? human capital investment in universities. Asian Journal of Education and Social Studies, 11(1), 2136.

https://doi.org/10.9734/AJESS/2020 /v11i130281

Morgenroth, T., \& Peters, K. (2015). The motivational theory of role modeling: how role models influence role aspirants' goals. Review of General Psychology, 1(2), 1-21. https://doi.org/10.1037/gpr0000059

Ndofirepi, A., Makaye, J., \& Ndofirepi, E. (2012). To discipline or to punish? A critical discourse on schooling in South Africa. Greener Journal of Educational Research, 2(4), 83-90. https://doi.org/10.15580/GJER.2012. 4.103112182

Obeng-denteh, W. (2011). The impact of student and teacher absenteeism on student performance at the junior high school: the case of the kumasi-metro school district. Continental Journal Education Research, 4(1), 7-17.

Pemerintah Indonesia. Peraturan 
pemerintah republik indonesia nomor 53 tahun 2010 tentang disiplin pegawai negeri sipil (2010). Jakarta.

Pramiyati, A. (2014). Identifikasi penyebab rendabnya kedisiplinan siswa kelas $v$ sd negeri salam i, kecamatan salam, magelang tabun ajaran 2013/2014. Universitas Negeri Yogyakarta.

Roos, R. (2003). Legal requirements for school rules and disciplinary sanctions. Koers, 68(4), 481-498.

Rumokoy, F. S. (2019). The influence of reward and punishment toward employee's performance at Bank ndonesia Branch Manado. EMBA, 7(1), 471-480.

Adlya, S. I., Yusuf, A. M., \& Effendi, Z. M. (2020). The contribution of self control to students ' discipline. Journal of Counseling and Educational Technology, 3(1), 1-5.

Chairilsyah, D. (2019). Educating children to be a discipline person. Jurnal PAJAR (Pendidikan Dan Pengajaran), 3(9), 12821288.

Ensom, R., Rsw, M. S. W., Assembly, G., Nations, U., \& States, U. (2012). Physical punishment of children: lessons from 20 years of research. CMAJ, 184(12), 1373-1377. https://doi.org/10.1503/cmaj.121070

Gorbunovs, A., Kapenieks, A., \& Cakula, S. (2016). Self-discipline as a Key
Indicator to Improve Learning Outcomes in e-learning Self-discipline as a key indicator to improve learning outcomes in e- learning environment. Procedia - Social and Behavioral Sciences, 231(November), 256-262. https://doi.org/10.1016/j.sbspro.2016 .09 .100

Habibi, I., \& Supriatno, T. (2020). Charity Punishment in Islamic Boarding School to Improving Santri Discipline. Naz̧bruna: Jurnal Pendidikan Islam, 3(3), 342-354. https://doi.org/10.31538/nzh.v3i3. 767

Hurd, N. M., \& Zimmerman, M. (2011). Role model behavior and youth violence: a study of positive and negative effects. The Journal of Early Adolescence, $\quad 1(4), \quad 323$. https://doi.org/10.1177/02724316103 63160

Jacobson, S. L. (2019). Attendance incentives and teacher absenteeism. In Planning and Changing (p. 81).

Kedia, G., Brohmer, H., Scholten, M., \& Corcoran, K. (2019). Improving selfcontrol: the influence of role models on intertemporal choices. Original Research, $\quad 10(8), \quad 1-12$. https://doi.org/10.3389/fpsyg.2019.01 722

Mahmudah, F. N. (2016). Keefektifan 
Human Capital Investment Pendidikan

Tenaga Kependidikan di Universitas

Negeri Yogyakarta. Jurnal Akuntabilitas

Manajemen Pendidikan, 4(1), 77-87.

Retrieved

from

https://doi.org/10.21831/amp.v4i1.82

01

Mahmudah, F. N., \& Cahya, E. (2020).

What makes employees productive and

have high performance? human capital investment in universities. Asian Journal of Education and Social Studies, 11(1), 2136.

https://doi.org/10.9734/AJESS/2020 /v11i130281

Ma`arif, M. A. (2018). Analisis Strategi Pendidikan Karakter Melalui Hukuman Preventif. Ta'allum: Jurnal Pendidikan Islam, 6(1), 31-56. https://doi.org/10.21274/taalum.20 18.6.1.31-56

Morgenroth, T., \& Peters, K. (2015). The motivational theory of role modeling: how role models influence role aspirants' goals. Review of General Psychology, 1(2), 1-21. https://doi.org/10.1037/gpr0000059

Ndofirepi, A., Makaye, J., \& Ndofirepi, E. (2012). To discipline or to punish? A critical discourse on schooling in South Africa. Greener Journal of Educational Research, 2(4), 83-90. https://doi.org/10.15580/GJER.2012.

\subsection{2}

Nur Hakim, M., \& Rahayu, F. D. (2019). Pembelajaran Saintifik Berbasis Pengembangan Karakter. Ną̧bruna: Jurnal Pendidikan Islam, 2(1), 1-27. https://doi.org/10.31538/nzh.v2i1. 148

Obeng-denteh, W. (2011). The impact of student and teacher absenteeism on student performance at the junior high school: the case of the kumasi-metro school district. Continental Journal Education Research, 4(1), 7-17.

Pemerintah Indonesia. Peraturan pemerintah republik indonesia nomor 53 tahun 2010 tentang disiplin pegawai negeri sipil (2010). Jakarta.

Pramiyati, A. (2014). Identifikasi penyebab rendahnya kedisiplinan siswa kelas $v$ sd negeri salam $i$, kecamatan salam, magelang tabun ajaran 2013/2014. Universitas Negeri Yogyakarta.

Roos, R. (2003). Legal requirements for school rules and disciplinary sanctions. Koers, 68(4), 481-498.

Rumokoy, F. S. (2019). The influence of reward and punishment toward employee's performance at Bank ndonesia Branch Manado. EMBA, 7(1), 471-480.

Rofiq, M. H. (2017). Kedisiplinan Siswa Melalui Hukuman Dalam Perspektif Stakeholder Pendidikan. Nidhomul 
Nidhomul Haq, Vol 6, Issue 1, 2021

\author{
Haq: Jurnal Manajemen Pendidikan \\ Islam, $\quad 2(2), \quad$ 82-94. \\ https://doi.org/10.31538/ndh.v2i2. \\ 25
}

Rosyad, A. M., \& Maarif, M. A. (2020).

Paradigma Pendidikan Demokrasi

Dan Pendidikan Islam Dalam

Menghadapi Tantangan Globalisasi

Di Indonesia. Ną̧runa: Jurnal

Pendidikan Islam, 3(1), 75-99.

https://doi.org/10.31538/nzh.v3i1.

491 